\title{
Hop dry matter yield and cone quality responses to amino acid and potassium-rich foliar spray applications
}

\section{Sandra Afonso, Margarida Arrobas, Jorge Sá Morais \& M. Ângelo Rodrigues}

To cite this article: Sandra Afonso, Margarida Arrobas, Jorge Sá Morais \& M. Ângelo Rodrigues (2021) Hop dry matter yield and cone quality responses to amino acid and potassium-rich foliar spray applications, Journal of Plant Nutrition, 44:14, 2042-2056, DOI: 10.1080/01904167.2021.1889597

To link to this article: https://doi.org/10.1080/01904167.2021.1889597

\section{Published online: 23 Feb 2021.}

Submit your article to this journal $\sqsubset$

Џ Article views: 72

à

View related articles $\sqsubset$

View Crossmark data $₫$ 


\title{
Hop dry matter yield and cone quality responses to amino acid and potassium-rich foliar spray applications
}

\author{
Sandra Afonso (D), Margarida Arrobas (D), Jorge Sá Morais, and M. Ângelo Rodrigues \\ Centro de Investigação de Montanha, Instituto Politécnico de Bragança, Bragança, Portugal
}

\begin{abstract}
The use of amino acid and K-rich foliar sprays was evaluated in a commercial hop field in North-eastern Portugal. Four applications of an amino acid-rich foliar spray were performed in place of a second side dress $\mathrm{N}$ application of $\sim 70 \mathrm{~kg} \mathrm{~N}^{-1}$, which is usually applied by the farmer. The K-rich foliar spray was applied once at the cone developing stage as a supplement to the farmer's fertilization plan. The amino acid-enriched foliar spray maintained crop dry matter yield at the levels of the control treatment and increased cone alpha-acids concentration (41.8\% in 2018 and $9.3 \%$ in 2019). Foliar K did not increase cone dry matter yield, cone size or bitter acid concentration. Tissue $\mathrm{K}$ concentration was not significantly affected by foliar treatments whereas the application of $\mathrm{K}$ seemed to increase $\mathrm{N}$ uptake, with leaves and stems being the predominant allocation tissues. Both foliar treatments increased leaf and stem $\mathrm{Mg}$ concentrations. The results seem to emphasize the importance of amino acids in the biosynthesis of bitter acids, while $\mathrm{K}$ and $\mathrm{Zn}$ seemed to play an important secondary role, maybe related to $\mathrm{N}$ metabolism and its reduction into amino acids. The concentrations of total phenols in cones and leaves were lower in the foliar treatments in comparison to the control, and the higher values registered in leaves. In this study, the use of amino acids as a foliar spray provided an interesting result, since they maintained cone dry matter yield and increased cone bitter acid concentration with reduced $\mathrm{N}$ use.
\end{abstract}

\section{ARTICLE HISTORY}

Received 27 August 2020

Accepted 29 September 2020

\section{KEYWORDS}

Alpha and beta-acids; foliar fertilization; hop dry matter yield; hop quality;

Humulus lupulus

\section{Introduction}

Commercial hop (Humulus lupulus L.) fields of North-eastern Portugal are grown under the European Union norms of integrated crop management which allow the use of conventional mineral fertilizers. Hop is a climbing plant, exceeding $7 \mathrm{~m}$ in height. The biomass that the plant produces is huge, which makes it a highly demanding crop for nutrients, in particular for nitrogen (N), the nutrient required most for plant growth (Kraiser et al. 2011; Turner et al. 2011). Hop is a crop of high operational costs, which causes farmers to search constantly for more economical and/or effective alternatives to increase crop yield and quality.

$\mathrm{N}$ is taken up by plant roots mainly as nitrate $\left(\mathrm{NO}_{3}{ }^{-}\right)$and ammonium $\left(\mathrm{NH}_{4}{ }^{+}\right)$ions, and to a lesser extent in the form of amino acids (Lambers, Chapin, and Pons 2008; McAllister, Beatty, and Good 2012). $\mathrm{NO}_{3}{ }^{-}$is the predominant form of $\mathrm{N}$ taken up by plants in agricultural well aerated soils, $\mathrm{NH}_{4}^{+}$in non-fertilized soils or waterlogged conditions, and amino acids in areas of reduced ammonification and nitrification such as in boreal forests (Hawkesford et al. 2012; Schulze et al. 2019). When $\mathrm{NO}_{3}{ }^{-}$is the $\mathrm{N}$ form taken up by the plant, it needs to be reduced to 
$\mathrm{NH}_{3} / \mathrm{NH}_{4}{ }^{+}$to be assimilated into amino acids, which has a high energy cost to the plant. $\mathrm{NH}_{4}^{+}$ resulting from $\mathrm{NO}_{3}{ }^{-}$reduction, or taken up directly from the soil, needs to be quickly assimilated since it is toxic to the plant (Lal 2018a; Schulze et al. 2019). Thus, the uptake of a more reduced form of $\mathrm{N}$, such as amino acids, may have several benefits to the plant which firstly include the lower biosynthetic cost (Lambers, Chapin, and Pons 2008). Moreover, soil inorganic N fertilization is usually associated with reduced $\mathrm{N}$ use efficiency and a high risk of environmental contamination, mainly due to nitrate leaching, denitrification and ammonia volatilization (Dimkpa et al. 2020). Amino acids can also have a biostimulant effect on plants, which increases their growth and development, and can reduce the need for fertilizers (Halpern et al. 2015).

Amino acid-based fertilizers may be applied to the soil or as foliar sprays (Drobek, Frac, and Cybulska 2019). Foliar applications are more orientated to the target organs, with lesser amounts being supplied. Although macronutrient requirement in high-yielding crops is unlikely to be met with foliar sprays (Fageria et al. 2009), partial replacement of conventional fertilization may benefit crop yield while reducing production costs and environmental damage. Positive effects of amino acid-containing biostimulants in the increasing of growth and yield have been commonly reported in horticultural crops (Drobek, Frac, and Cybulska 2019). In fruit crops, the application of amino acids as foliar sprays can also be effective in improving yield and fruit quality (Abd ElRazek et al. 2018; Ilie, Petrișor, and Hoza 2018). Regarding hops, there is little data on the use of biostimulants or amino acid-based formulations. Procházka et al. (2018) tested a set of biologically active substances in hop, one of which was based on a seaweed (Ascophyllum nodosum) extract, containing macro and micronutrients and amino acids. This treatment, however, did not produce relevant results in terms of hop yield and quality in comparison to the many other fertilizing materials.

Hop cones are the most valuable plant part, usually used in the brewing industry (Almaguer et al. 2014). It is in the lupulin glands of the hop cones that the bitter alfa $(\alpha)$ - and beta $(\beta)$-acids are synthetized, which contribute to the bitter flavor of beer, its preservation, and foam stability (Almaguer et al. 2014). The contribution of $\alpha$-acids to beer bitterness is much more important than $\beta$-acids and the content of both in hop cones has to be measured to determine the addition ratio to the beer brew (Small 2016). Consequently, the income of hop farmers depends greatly on the bitter acid content in hop cones. In this regard, factors promoting the size and quality of hop cones are of ultimate importance. The effect of potassium $(\mathrm{K})$ on the growth phase of flowers and fruits is well known (Hawkesford et al. 2012; Hasanuzzaman et al. 2018), including its role in the development of hop cones (Gingrich, Hart, and Christensen 1994).

In plants, $\mathrm{K}$ does not form part of organic structures, although it has important roles in several biological processes such as photosynthesis, respiration, osmoregulation, phloem transport and biosynthesis of protein, sugar and starch, which ultimately contribute to plant growth and fruit quality (Kathpalia and Bhatla 2018; Schulze et al. 2019). The use of K-based foliar sprays is currently increasing mainly due to their potential positive effects on crop quality (Dean 2019). Valentinuzzi et al. (2018) found that foliar applications of $\mathrm{K}$ did not affect strawberry (Fragaria $\times$ ananassa) fruit yield but improved several quality parameters. In a review of the subject, Ahmad et al. (2018) reported that the positive effects of $\mathrm{K}$ application are usually more consistent under drought conditions.

Amino acid-based fertilizers are having an increasing use among hop producers in Portugal. In this region, hop farmers often apply foliar $\mathrm{K}$ sprays late in the growing season to increase cone size and quality, but without the results ever being monitored by experimental work. Thus, there is a scarcity of data on the effects of amino acid or K-rich foliar sprays in hop fields in Portugal as well as in other hop producing countries. In order to reduce the gap in the data on such an important subject to hop farmers, the present research has two main objectives: i) to evaluate the effects on plant nutritional status, hop yield and quality of an amino acid-enriched foliar spray, in place of a proportion of the $\mathrm{N}$ applied to the soil as a side dressing; and ii) to 
Table 1. Selected soil properties (average \pm standard deviation) from composite samples collected in the rows and between rows at $0-30 \mathrm{~cm}$ depth.

\begin{tabular}{lcr}
\hline Soil properties & In rows & Between rows \\
\hline $\mathrm{pH}_{\mathrm{H} 2 \mathrm{O}}$ & $5.7 \pm 0.29$ & $5.8 \pm 0.15$ \\
Organic carbon $\left(\mathrm{g} \mathrm{kg}^{-1}\right)^{\mathrm{a}}$ & $20.3 \pm 0.54$ & $16.9 \pm 0.45$ \\
Extractable $\mathrm{P}\left(\mathrm{mg} \mathrm{P}_{2} \mathrm{O}_{5} \mathrm{~kg}^{-1}\right)^{\mathrm{b}}$ & $268.4 \pm 123.8$ & $276.6 \pm 122.1$ \\
Extractable $\mathrm{K}\left(\mathrm{mg} \mathrm{K}_{2} \mathrm{O} \mathrm{kg}\right)^{\mathrm{b}}$ & $376.8 \pm 116.8$ & $326.5 \pm 53.5$ \\
Exchangeable $\mathrm{Ca}\left(\mathrm{cmol} \mathrm{kg}^{-1}\right)^{\mathrm{c}}$ & $5.2 \pm 1.56$ & $4.2 \pm 1.11$ \\
Exchangeable $\mathrm{Mg}\left(\mathrm{cmolc} \mathrm{kg}^{-1}\right)^{\mathrm{c}}$ & $1.3 \pm 1.79$ & $0.6 \pm 0.11$ \\
Exchangeable K $\left(\mathrm{cmol}_{\mathrm{c} \mathrm{kg}}\right)^{\mathrm{c}}$ & $0.7 \pm 0.23$ & $0.6 \pm 0.20$ \\
Exchangeable Na $\left(\mathrm{cmol}_{\mathrm{c} \mathrm{kg}}{ }^{-1}\right)^{\mathrm{c}}$ & $0.04 \pm 0.01$ & $0.1 \pm 0.03$ \\
Exchangeable acidity $\left(\mathrm{cmol}_{\mathrm{c}} \mathrm{kg}^{-1}\right)^{\mathrm{c}}$ & $0.3 \pm 0.14$ & $0.2 \pm 0.10$ \\
Cation-exchange capacity $\left(\mathrm{cmol}_{\mathrm{c}} \mathrm{kg}^{-1}\right)$ & $7.8 \pm 2.13$ & $6.0 \pm 1.33$ \\
Extractable $\mathrm{B}\left(\mathrm{mg} \mathrm{kg}^{-1}\right)^{\mathrm{d}}$ & $1.0 \pm 0.19$ & $0.5 \pm 0.17$ \\
Extractable Fe $\left(\mathrm{mg} \mathrm{kg}^{-1}\right)^{\mathrm{e}}$ & $219.6 \pm 57.2$ & $253.8 \pm 51.8$ \\
Extractable $\mathrm{Mn}\left(\mathrm{mg} \mathrm{kg}^{-1}\right)^{\mathrm{e}}$ & $144.7 \pm 28.2$ & $194.5 \pm 19.3$ \\
Extractable $\mathrm{Zn}\left(\mathrm{mg} \mathrm{kg}^{-1}\right)^{\mathrm{e}}$ & $4.9 \pm 1.91$ & $4.6 \pm 1.57$ \\
Extractable $\mathrm{Cu}\left(\mathrm{mg} \mathrm{kg}^{-1}\right)^{\mathrm{e}}$ & $11.7 \pm 2.59$ & $12.4 \pm 1.68$ \\
\hline
\end{tabular}

${ }^{a}$ Wet oxidation (Walkley-Black);

begner-Riehm;

${ }^{\mathrm{C} A m m o n i u m}$ acetate, $\mathrm{pH}$ 7;

${ }^{\mathrm{d}}$ Hot water, azomethine-H;

${ }^{\mathrm{e}}$ Ammonium acetate and EDTA.

evaluate the effects on cone yield and quality of a K-rich foliar spray applied at cone developing stage, as a supplement to soil fertilization.

\section{Materials and methods}

\section{Field experiments characterization}

The field trial was conducted during two growing seasons, from 2018 to 2019, in a hop farm in Pinela $\left(41^{\circ} 40^{\prime} 33.6^{\prime \prime} \mathrm{N} 6^{\circ} 44^{\prime} 32.7^{\prime \prime} \mathrm{W}\right)$, NE Portugal. The region benefits from a Mediterranean-type climate (average annual air temperature of $12.7^{\circ} \mathrm{C}$; annual precipitation of $772.8 \mathrm{~mm}$ ). Some of physical and chemical soil properties, from composite soil samples collected at $0-30 \mathrm{~cm}$ depth, in the rows and between rows, previously to the beginning of the experiment, are presented in Table 1.

The cultivar Nugget is grown in a $7 \mathrm{~m}$ conventional high trellis system, with concrete poles, connected with cable, in a " $\mathrm{V}$ " design system. The plants are mechanically pruned in late winter. In summer, the hop is irrigated by flooding the space between rows. Several tillage passes are performed every year to prepare the ridges for irrigation, control weeds and remove soil crusts to allow water infiltration during summer. The farmer follows a crop health protection programme against downy mildew (Pseudoperonospora humuli), powdery mildew (Podosphaera macularis), several aphids and mites, which he applies as needed.

The experiment was arranged as a fully randomized design with three fertilizer treatments and four replications (four random plants of equivalent size selected before the application of the fertilizers). The fertilization treatments were: 1 ) Control, as the fertilization plan performed by the farmer, consisting of the application of $500 \mathrm{~kg} \mathrm{ha}^{-1}$ of a compound NPK fertilizer (7:14:14) late in winter, followed by two side dress $\mathrm{N}$ applications performed during the growing season, the first with $\sim 250 \mathrm{~kg} \mathrm{ha}^{-1}$ of nitromagnesium $\left(27 \% \mathrm{~N}\right.$ as $\left.\mathrm{NH}_{4} \mathrm{NO}_{3}+3.5 \% \mathrm{MgO}+3.5 \% \mathrm{CaO}\right)$ and the second with $\sim 450 \mathrm{~kg} \mathrm{ha}^{-1}$ of calcium nitrate $\left.\left(15.5 \% \mathrm{~N}^{2} \mathrm{NO}_{3}^{-}+27 \% \mathrm{CaO}\right) ; 2\right)+\mathrm{K}$, consisting of the same fertilization plan referred to the control treatment with an additional application of a K-rich foliar spray at cone development stage; and 3) AA, where the second side dress $\mathrm{N}$ application of the control treatment was replaced by four applications of an amino acid-based foliar spray. 
The K-rich foliar spray contained $(\mathrm{w} / \mathrm{w}) 31 \% \mathrm{~K}_{2} \mathrm{O}, 3 \% \mathrm{~N}$ and $1 \%$ EDTA and was applied at a rate of $41 \mathrm{ha}^{-1}$ at the end of July (July $30^{\text {th }} 2018$ and July $29^{\text {th }} 2019$ ). The amino acid-enriched foliar spray contained $(\mathrm{w} / \mathrm{w}) 53 \%$ of total amino acids ( $8.6 \%$ free amino acids), $9 \%$ total $\mathrm{N}(8.6 \%$ organic $\mathrm{N})$ and $54 \%$ total organic matter (27.2\% organic carbon) and was applied at a rate of $2.51 \mathrm{ha}^{-1}$, four times during the growing season (June $20^{\text {th }}$, July $8^{\text {th }}$, July $24^{\text {th }}$ and July $30^{\text {th }} 2018$, and June $13^{\text {th }}$, June $28^{\text {th }}$, July $15^{\text {th }}$ and July $\left.29^{\text {th }} 2019\right)$.

\section{Data acquisition in the field and tissue sampling}

Estimates of the leaf greenness were measured by using the portable SPAD (Soil and Plant Analysis Development)-502 Plus chlorophyll meter, which provide adimensional values, proportional to the chlorophyll content of the leaves. The device measures the transmittance of light through the leaves in two wavelengths, at $650 \mathrm{~nm}$ (red light absorbed by chlorophyll) and $940 \mathrm{~nm}$ (infrared light, non-absorbed by chlorophyll). Thirty readings for each measurement were taken from the distal lobe of young fully expanded leaves on July $16^{\text {th }} 2018$ and July $5^{\text {th }} 2019$ in the Control and AA treatments, seven days after the second application of amino acids. SPAD readings were taken a second time on August $7^{\text {th }} 2019$ for all treatments, after the application of the K-rich foliar spray and the last application of the amino acids.

A Normalized Difference Vegetation Index (NDVI) was determined by using the hand-held FieldScout CM 1000. The meter senses and measures the ambient light at the wavelength of $660 \mathrm{~nm}$ and the reflected light (non-absorbed by leaf chlorophyll) at $840 \mathrm{~nm}$ wavelength. The NDVI values (between -1 and 1) are calculated from the equation [(\%Near Infrared - \%Red)/ (\%Near Infrared $+\%$ Red)]. The measurements were taken in the same leaf part and dates as SPAD readings.

Chlorophyll a fluorescence and OJIP transient was determined by using the OS$30 \mathrm{p}+$ chlorophyll meter through the dark adaptation protocols $\mathrm{F}_{\mathrm{V}} / \mathrm{F}_{\mathrm{M}}, \mathrm{F}_{\mathrm{V}} / \mathrm{F}_{0}$ and the advanced OJIP test. $\mathrm{F}_{\mathrm{M}}, \mathrm{F}_{0}$ and $\mathrm{F}_{\mathrm{V}}$ are, respectively, maximum, minimum and variable fluorescence from dark adapted leaves, and $\mathrm{F}_{\mathrm{V}} / \mathrm{F}_{\mathrm{M}}=\left(\mathrm{F}_{\mathrm{M}^{-}}-\mathrm{F}_{0}\right) / \mathrm{F}_{\mathrm{M}}$ and $\mathrm{F}_{\mathrm{V}} / \mathrm{F}_{0}=\left(\mathrm{F}_{\mathrm{M}^{-}}-\mathrm{F}_{0}\right) / \mathrm{F}_{0}$. The OJIP test provides origin fluorescence at $20 \mu \mathrm{s}(\mathrm{O})$, fluorescence at $2 \mathrm{~ms}(\mathrm{~J})$, fluorescence at $30 \mathrm{~ms}$ (I) and maximum fluorescence $\left(\mathrm{P}\right.$, or $\left.\mathrm{F}_{\mathrm{M}}\right)$. Measurements were taken from the distal lobe of fully expanded young leaves, after a period of dark adaptation longer than $35 \mathrm{~min}$ in the same dates as SPAD readings.

In the first date of field measurements, at the middle of the growing season (July $16^{\text {th }} 2018$ and July $5^{\text {th }} 2019$ ), leaf samples were taken at $\sim 2 \mathrm{~m}$ height for elemental analysis. At harvest (August $27^{\text {th }}$ to $31^{\text {st }} 2018$ and August $29^{\text {th }}$ to $31^{\text {st }} 2019$ ), the aboveground biomass was cut at ground level and separated into two samples of leaves (bottom and upper halves), stems and cones and weighed in fresh. Simultaneously, subsamples of each plant part were weighed again in fresh, oven dried at $70^{\circ} \mathrm{C}$ and weighed dry for determination of dry matter yield of the different plant parts. Additionally, subsamples of 30 dried cones for each replication were randomly selected for determination of the dry mass of individual cones. Thereafter, subsamples of all tissues were ground and analyzed for elemental composition.

\section{Laboratory analyses}

The soil samples were oven-dried at $40^{\circ} \mathrm{C}$ and sieved in a mesh of $2 \mathrm{~mm}$. The samples were analyzed for $\mathrm{pH}\left(\mathrm{H}_{2} \mathrm{O}\right)$ (soil: solution, 1:2.5), cation-exchange capacity (ammonium acetate, $\mathrm{pH} 7.0$ ), organic carbon (wet digestion, Walkley-Black method) and extractable phosphorus (P) and K (Egner-Riehm method). Soil boron (B) was extracted by hot water and the extracts analyzed by the azomethine- $\mathrm{H}$ method. The analytical procedures for these analyses were performed according to Van Reeuwijk (2002). The availability of other micronutrients, cooper $(\mathrm{Cu})$, iron $(\mathrm{Fe})$, zinc $(\mathrm{Zn})$ and manganese $(\mathrm{Mn})$, in the soil was determined by atomic absorption spectrometry after 
extraction with ammonium acetate and EDTA, according to the method described by Lakanen and Erviö (1971).

Elemental tissue analyses were performed by Kjeldahl $(\mathrm{N})$, colorimetry (B and P), flame emission spectrometry $(\mathrm{K})$ and atomic absorption spectrophotometry [calcium $(\mathrm{Ca})$, magnesium $(\mathrm{Mg})$, $\mathrm{Cu}, \mathrm{Fe}, \mathrm{Zn}$ and $\mathrm{Mn}$ ] methods after nitric digestion of the samples (Temminghoff and Houba 2004). Nitrate concentration in hop cones was determined according to Clescerl, Greenberg, and Eaton (1998), by UV-vis spectrophotometry in a water extract (dry cone:solution, 2.5:50). Bitter acids ( $\alpha$ - and $\beta$-acids) in hop cones were extracted with methanol and diethyl ether by HPLC, according with Analytica EBC 7.7. method (EBC Analysis committee 1998).

\section{Data analysis}

Data was subject to one-way analysis of variance, according to the experimental design, to check for significant differences between fertilizer treatments, using SPSS program v. 25. When significant differences were found, the means were separated by Tukey HSD test $(\alpha=0.05)$. A correlation analysis was also performed for cones data with Spearman coefficient.

\section{Results}

\section{Plant dry matter yield}

Dry matter yield of total aboveground biomass or plant part (stems, leaves and cones) did not significantly differ among treatments in both years (Figure 1). Total aboveground dry matter yield varied from 1330 and $1494 \mathrm{~g} \mathrm{plant}^{-1}$ in 2018 and from 1287 and $1524 \mathrm{~g} \mathrm{plant}^{-1}$ in 2019 . The dry matter of cones was found between 397 and $454 \mathrm{~g} \mathrm{plant}^{-1}$ and 395 and $485 \mathrm{~g} \mathrm{plant}^{-1}$, respectively in 2018 and 2019.

The size of the cones also did not significantly vary between treatments (Data not shown). Average values varied between 0.22 and $0.26 \mathrm{~g} \mathrm{cone}^{-1}$ in 2018 and 0.20 and $0.22 \mathrm{~g}$ cone $\mathrm{e}^{-1}$ in 2019.

\section{Tissue nutrient concentration and removal}

For the majority of the nutrients, the concentration in the leaves taken at $2 \mathrm{~m}$ height during the growing season, significantly varied between control and AA treatments (Table 2). The control treatment tended to show higher leaf concentration of N, P, Mn, Zn (significant differences in 2018 ) and $\mathrm{K}$ (significant differences in both years). The AA treatment showed significantly higher values of $\mathrm{Mg}$ (in 2018), $\mathrm{Fe}$ (in 2018) and B (in 2019). $\mathrm{Ca}$ and $\mathrm{Cu}$ did not significantly vary between the control and AA treatments. Comparing the average leaf nutrient concentrations to the sufficiency ranges reported for hop mature leaves, several nutrients were found below or above, respectively to the lower and upper limits of the adequate range. Leaf $\mathrm{P}$ and $\mathrm{Mn}$ levels, consistently lower and higher than the sufficiency ranges, were probably the most noticeable cases. Average P levels were always below $2.2 \mathrm{~g} \mathrm{~kg}^{-1}$, whereas the sufficiency range is set at 2.7$5.4 \mathrm{~g} \mathrm{~kg}^{-1}$. Average $\mathrm{Mn}$ values were higher than $300 \mathrm{mg} \mathrm{kg}^{-1}$ in both treatments and years, whereas the upper limit of the sufficiency range is $125 \mathrm{mg} \mathrm{kg}^{-1}$. Fe also tended to appear out of the sufficiency range. In 2019, for instance, the AA treatment registered a leaf Fe concentration of $253 \mathrm{mg} \mathrm{kg}^{-1}$, a value highly above the upper limit of the sufficiency range set at $98 \mathrm{mg} \mathrm{kg}^{-1}$.

At harvest, there were also found significant differences between fertilizer treatments for all the nutrients, at least for one of the years or leaf position in the canopy. The results of the bottom half leaves were also shown in Table 2. Those of the top half leaves were not present, due to their similarities. The most relevant trends probably are: the higher leaf $\mathrm{K}$ levels in the control 


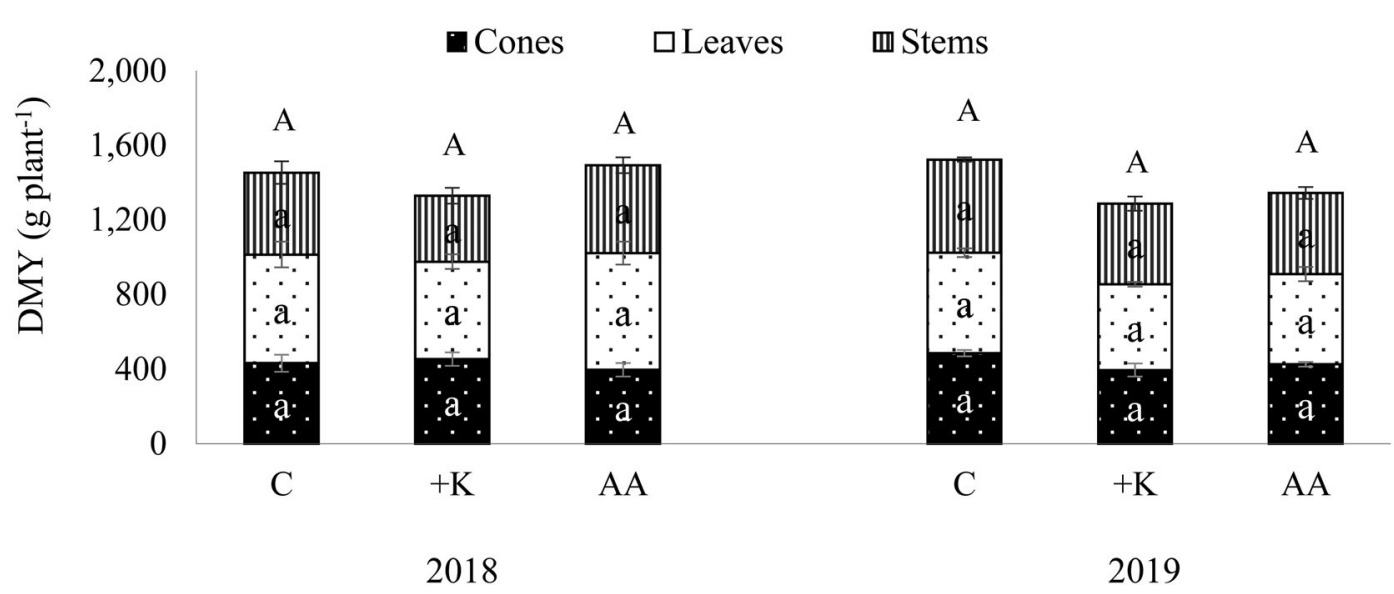

Figure 1. Dry matter yield (DMY) of hop plant parts and total, in 2018 and 2019, as a function of fertilizer treatment (C, control; $+\mathrm{K}$, potassium-rich foliar spray; AA, amino acid-based foliar spray). Within each year, means followed by the same letter (lower case for each plant tissue and uppercase for total) are not statistically different by Tukey HSD test $(\alpha=0.05)$. Error bars are the confidence intervals of the means $(\alpha=0.05)$.

and $+\mathrm{K}$ treatments in comparison to AA treatment; the higher levels of leaf $\mathrm{N}$ in the $+\mathrm{K}$ treatment; the lower leaf $\mathrm{Mg}$ levels in the control treatment; and the higher leaf Fe levels in the AA treatment. No consistency was found for punctual significant differences found for the other treatments. Leaf $\mathrm{Mn}$ and Fe levels appeared particularly higher than the values reported as sufficiency ranges.

The concentration of most of the nutrients in the stems significantly varied between fertilizer treatments, at least in one of the years, the exceptions being $\mathrm{K}$ and $\mathrm{Fe}$ (data not shown). However, average $\mathrm{K}$ concentration in stems was higher in control and $+\mathrm{K}$ treatments, following the trend observed in the leaves. Average stem $\mathrm{N}$ levels tended to be higher in the $+\mathrm{K}$ treatment and $\mathrm{P}, \mathrm{Mg}$ and $\mathrm{Zn}$ tended to be lower in the control treatment. A consistent trend was not observed for the other elements even for those in which significant differences were found in a single year.

Nutrient concentration in cones varied less than in the other plant tissues (Table 3). Significant differences among fertilizer treatments occurred only for five $(\mathrm{N}, \mathrm{P}, \mathrm{Ca}, \mathrm{Mn}$ and $\mathrm{Cu})$ of the ten nutrients analyzed at least in one year. The concentration of $\mathrm{K}, \mathrm{Mg}, \mathrm{Fe}, \mathrm{Zn}$ and $\mathrm{B}$ in the cones did not significantly vary among fertilizer treatments. The AA treatment showed the lower average cone $\mathrm{N}$ concentrations.

Plant nutrient removal did not significantly vary for N, P, Ca and B when appreciated by each plant tissue within each year or even when the sum of the total aboveground dry matter of the two years were analyzed (data not shown due to its extensity). For the majority of the other nutrients, significant differences between fertilizer treatments were found for a particular tissue and/or year, but when appreciated as the sum of all tissue parts and years, significant differences were only found for $\mathrm{Mn}$. In this particular case, the plants of the control treatment recovered more $\mathrm{Mn}$ than those of the $+\mathrm{K}$ treatment.

\section{SPAD, NDVI, chlorophyll fluorescence}

In 2018, SPAD readings, NDVI and chlorophyll fluorescence variables did not significantly vary with fertilizer treatments (data not shown). In 2019, SPAD values also did not differ significantly between treatments in any of the measuring dates (Table 4). Average values varied from 40.2 (July 2019, C treatment) to 43.4 (August 2019, AA treatment). NDVI significantly varied among the fertilizer treatments in the measurements of August 2019. In this date, the $+\mathrm{K}$ treatment gave 


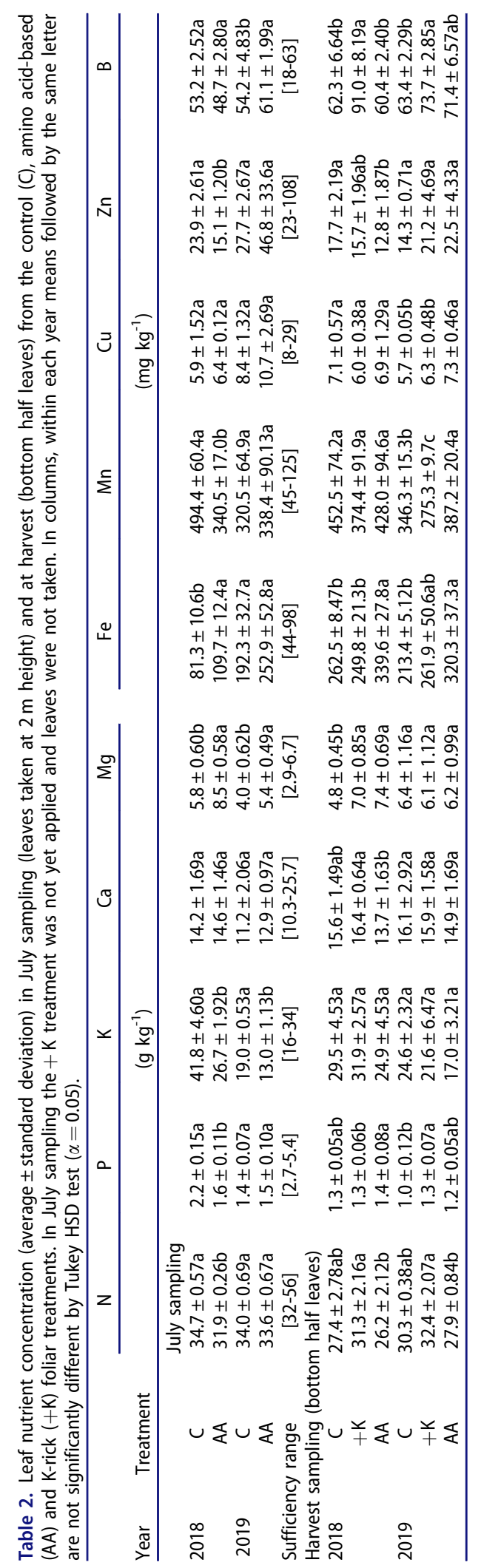




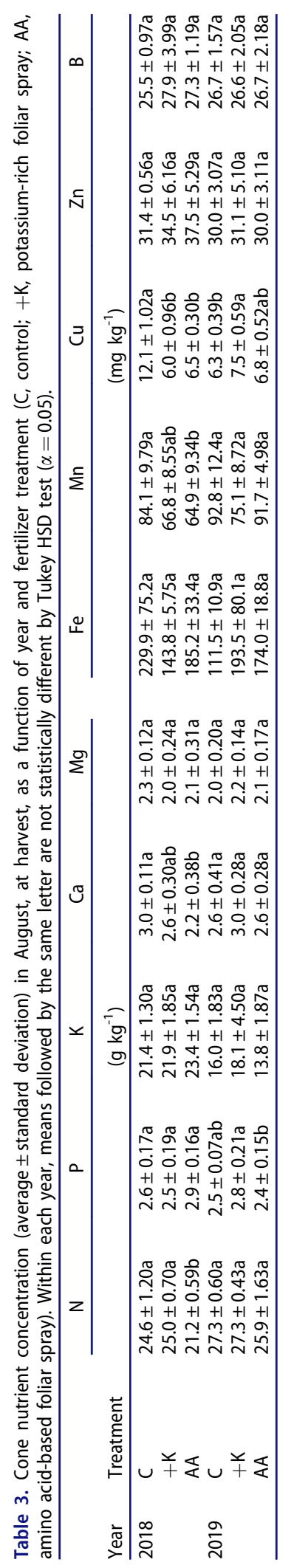




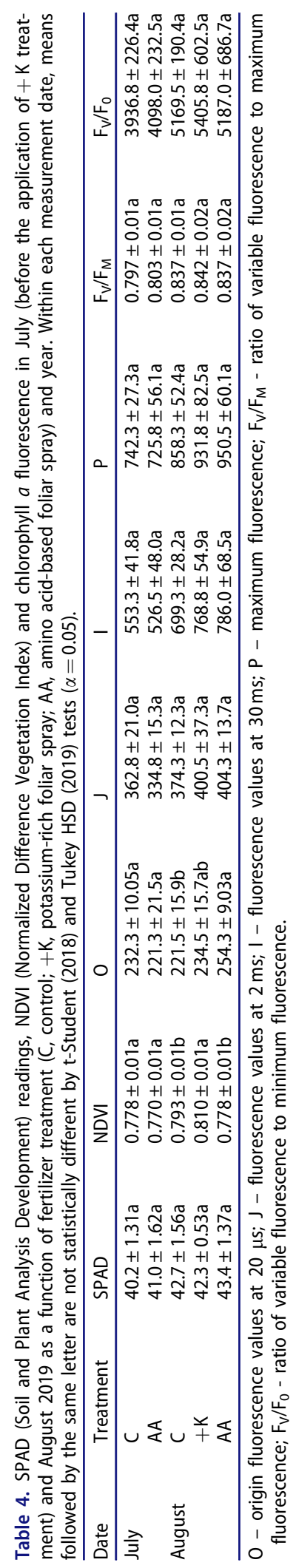




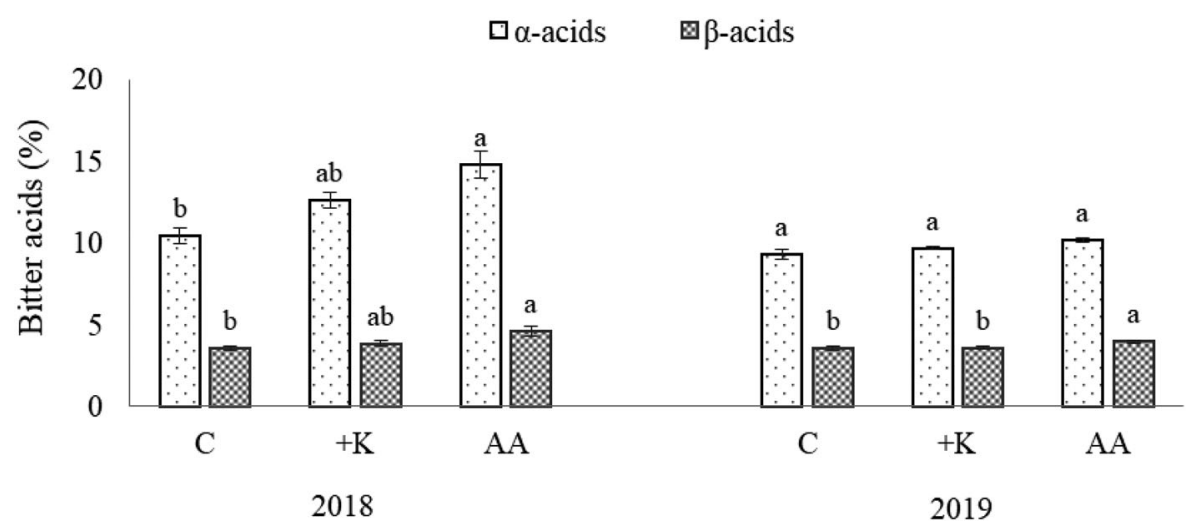

Figure 2. Cone $\alpha$ - and $\beta$-acids concentration in 2018 and 2019 as a function of fertilizer treatment (C, control; $+\mathrm{K}$, potassiumrich foliar spray; AA, amino acid-based foliar spray). Within each year, means followed by the same letter are not statistically different by Tukey HSD test $(\alpha=0.05)$. Error bars are the confidence intervals of the means $(\alpha=0.05)$.

significantly higher values than the control and AA treatments. Chlorophyll fluorescence variables showed also little sensitivity to the fertilizer treatments. Only in the $\mathrm{O}$ (origin), the values significantly differed among treatments in the measurement taken in august 2019.

\section{Bitter acids and nitrate concentration in the cones}

The concentration of $\alpha$-acids in the cones significantly varied between the fertilizer treatments only in 2018 (Figure 2). The concentration of $\alpha$-acids ranged from 10.4 to $14.8 \%$, respectively in the control and AA treatments. The concentration of $\beta$-acids, in turn, significantly varied between the fertilizer treatments in both years. The higher $\beta$-acids concentrations were also found in the AA treatment (4.60 and 3.96\%, respectively in 2018 and 2019), whereas the lower values were found in the control treatment $(3.57 \%$ in 2018 and $3.59 \%$ in 2019$)$. The nitrate $\left(\mathrm{NO}_{3}{ }^{-}\right)$concentration in hop cones did not significantly vary between treatments in any of the years (data not shown). Even so, it can be noted that the average values were consistently higher in the $+\mathrm{K}$ treatment.

\section{Total phenol concentration in the cones and leaves}

Total phenol concentration in cones and leaves in the samples collected at harvest in 2018 differed significantly between treatments for all tissues (Figure 3 ). In the cones, total phenol concentrations were significantly lower in $+\mathrm{K}$ in comparison to the other treatments. In the leaves, the higher values were found in the control treatment. The control treatment exhibited the higher average values in the cones and in the leaves. The effect of the treatments was more pronounced in the leaves than in the cones, the highest peaks being recorded in leaves in particular in those from the bottom of the canopy. Total phenol concentrations in cones ranged from $13.1(+\mathrm{K}$ treatment) to $19.9 \mathrm{mg} \mathrm{g}^{-1}$ extract (control treatment) and in leaves ranged from 40.5 (control treatment) to $9.6 \mathrm{mg} \mathrm{g}^{-1}$ extract (AA treatment).

\section{Correlation analysis in cone data}

Correlation analysis for cone data indicates some significant (and negative) correlations coefficients for bitter acids and $\mathrm{NO}_{3}{ }^{-}$in relation with cone nutrient concentrations (Table 5). The $\alpha$-acids seems to be significant and negatively correlated with $\mathrm{N}, \mathrm{Mn}$ and $\mathrm{Ca}$ and $\beta$-acids with $\mathrm{Ca}, \mathrm{Cu}, \mathrm{N}$ and $\mathrm{Mg}$. For $\mathrm{NO}_{3}{ }^{-}$, correlations were significant and negative with $\mathrm{K}$ and $\mathrm{Zn}$. 


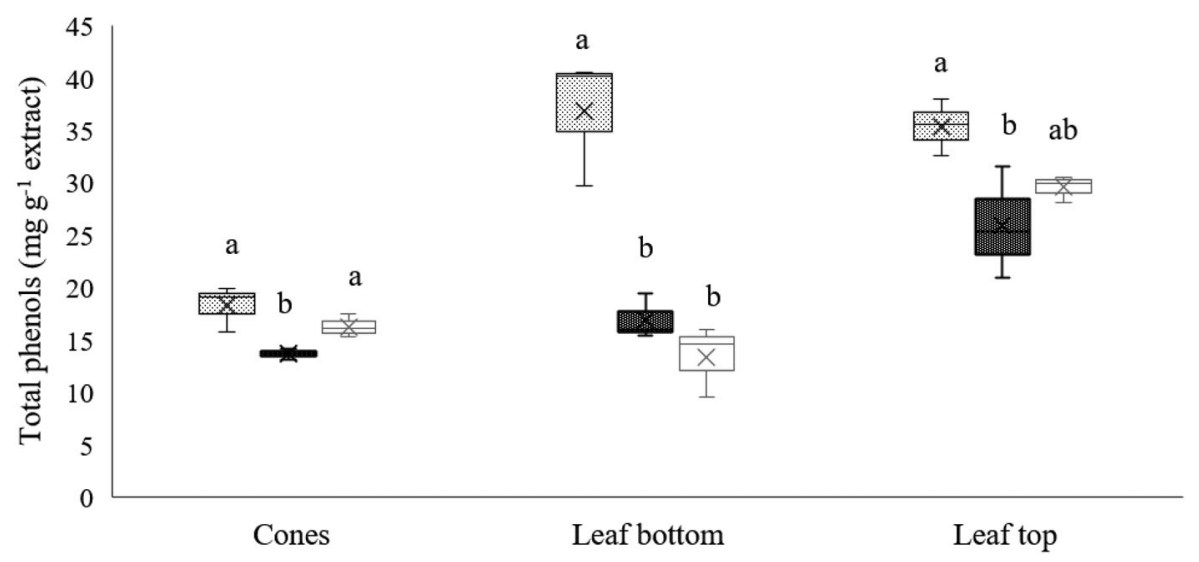

Figure 3. Total phenol concentration in the cones and leaves (from the bottom half and top half of the plants) in 2018, at harvest, as a function of fertilizer treatment $(C$, control; $+K$, potassium-rich foliar spray; $A A$, amino acid-based foliar spray). Means followed by the same letter are not statistically different by Tukey HSD test $(\alpha=0.05)$. Error bars are the confidence intervals of the means $(\alpha=0.05)$.

\section{Discussion}

The application of amino acids produced similar dry matter yield, including in the cones, as the control (the conventional fertilization plan). The result seems to mean that the fertilization programme of the farmer can undergo significant changes without affecting crop yield. In this experiment, amino acids were applied instead of the second side dress $\mathrm{N}$ application $(\sim 70 \mathrm{~kg} \mathrm{~N}$ $\mathrm{ha}^{-1}$ ). Amino acids are a source of $\mathrm{N}$ in a reduced form, with less biosynthetic cost in relation to mineral N (Lambers, Chapin, and Pons 2008), which can help to explain the result. Late application of $\mathrm{K}(+\mathrm{K}$ treatment) did not increase dry matter yield or cone size. Despite the high $\mathrm{K}$ requirements of hops (Gingrich, Hart, and Christensen 1994), data on the effects of foliar K fertilizers in hops has not been reported. In agreement with our findings, Valentinuzzi et al. (2018) also did not find any increase in fruit yield in strawberry, after the application of a K-rich foliar spray.

Leaf and stem $\mathrm{N}$ levels were consistently higher in the $+\mathrm{K}$ treatment in comparison with the $\mathrm{AA}$ and control treatments. The effect of $\mathrm{K}$ applications on the increase in tissue $\mathrm{N}$ levels was often recorded in other species (Abdelwanise et al. 2017; Shehata, El-Mogy, and Mohamed 2019). The AA treatment presented tissue $\mathrm{N}$ concentrations quite similar to the control, indicating the effectiveness of the amino acids applied as a foliar spray in sustaining the $\mathrm{N}$ nutritional status of the plants at the same level of the second side dress $\mathrm{N}$ application of $70 \mathrm{~kg} \mathrm{ha}^{-1}$. It was also found from previous studies an increase in $\mathrm{N}$ levels in plant tissues with the application of amino acids as foliar sprays (Abd El-Razek et al. 2018; Noroozlo, Souri, and Delshad 2019; Shehata et al. 2011).

The fertilizer treatments had little effect on tissue K levels. However, the values of the control and $+\mathrm{K}$ treatments were consistently higher than those of the AA treatment. The results of the present study may be related to soil $\mathrm{N}$ fertilization which in the control and $+\mathrm{K}$ treatments consisted of two side dress $\mathrm{N}$ applications, while in the AA treatment just one. The transport of $\mathrm{NO}_{3}{ }^{-}$from the roots to the shoots takes place via xylem along with $\mathrm{K}^{+}$as a counter-ion (Schulze et al. 2019), which may justify the increased tissue $\mathrm{K}$ levels found in those treatments.

Both foliar treatments ( $\mathrm{AA}$ and $+\mathrm{K}$ ) increased $\mathrm{Mg}$ concentrations in leaves and stems in comparison to the control. Leaf and stem Fe levels were consistently higher in the AA treatment in both years, and were significantly higher in bottom leaves. Noroozlo, Souri, and Delshad (2019) 
Table 5. Correlation matrix for bitter acids ( $\alpha$ - and $\beta$-acids) and nitrate $\left(\mathrm{NO}_{3}{ }^{-}\right)$with nutrient in hop cones, with Spearman correlation coefficients.

\begin{tabular}{lllllllllll}
\hline & $\mathrm{N}$ & $\mathrm{P}$ & $\mathrm{K}$ & $\mathrm{Ca}$ & $\mathrm{Mg}$ & $\mathrm{Fe}$ & $\mathrm{Mn}$ & $\mathrm{Cu}$ & $\mathrm{Zn}$ & $\mathrm{B}$ \\
\hline$\alpha$-acid & $-0.611^{* *}$ & -0.316 & 0.295 & $-0.478^{*}$ & -0.380 & 0.231 & $-0.558^{* *}$ & -0.343 & 0.054 & -0.250 \\
$\beta$-acid & $-0.462^{*}$ & -0.403 & -0.223 & $-0.580^{* *}$ & $-0.456^{*}$ & 0.076 & -0.251 & $-0.463^{*}$ & -0.129 & -0.337 \\
$\mathrm{NO}_{3}{ }^{-}$ & 0.191 & -0.221 & $-0.445^{*}$ & 0.124 & -0.047 & -0.317 & -0.004 & -0.275 & $-0.414^{*}$ & -0.027 \\
\hline
\end{tabular}

Significant correlations according to selected significance levels:

$*=0.05$,

$* *=0.01$.

found that glutamine and glycine amino acids, sprayed at 250 and $500 \mathrm{mg} \mathrm{L}^{-1}$, increased leaf $\mathrm{Mg}$ and $\mathrm{Fe}$ concentrations in basil (Ocimum basilicum), which is in agreement with the findings of the present study. The AA treatment association with higher Fe tissue levels could be due to the role of amino acids in nutrient transport. It is known that amino acids can chelate metals such as Fe, thereby increasing their assimilation through specific transporters (Halpern et al. 2015; Lal 2018b).

Tissue Mn concentrations were generally higher in the control and lower in the $+\mathrm{K}$ treatment. Leaf $\mathrm{Mn}$ concentrations were above the sufficiency range and $\mathrm{Mg}$ concentrations below, in particular in the control treatment. Although hops seem somewhat sensitive to Mn toxicity (Afonso, Arrobas, and Rodrigues 2020), applications of $\mathrm{K}$ may be able to alleviate the potential damage caused by excess $\mathrm{Mn}$ (Yu et al. 2020).

The concentration of nutrients in the cones varied less than in the other tissues, the results not being significant for most nutrients. However, the $+\mathrm{K}$ treatment presented slightly higher $\mathrm{K}$ levels in the cones in comparison to the control in both years, though differences were not statistically significant. The soil and the fertilization programme (the control treatment) seem to provide enough $\mathrm{K}$ to plants, as indicated by leaf $\mathrm{K}$ status in the control, generally being close to the upper limit of the sufficiency range (Bryson et al. 2014), which may have contributed to the lower efficacy of the $+\mathrm{K}$ treatment in increasing cone $\mathrm{K}$ levels.

Correlation analysis for cone data may help to clarify the trends of nutrient accumulation found in tissues. Results indicated $\mathrm{NO}_{3}{ }^{-}$strong and negatively correlated with $\mathrm{K}$ and $\mathrm{Zn}$. The negative association with $\mathrm{K}$ could be the result of $\mathrm{NO}_{3}{ }^{-}$reduction into amino acids, since $\mathrm{NO}_{3}{ }^{-}$is transported together with $\mathrm{K}$ as an accompanying cation being released with the $\mathrm{NO}_{3}{ }^{-}$reduction (Schulze et al. 2019). $\mathrm{Zn}$ is also involved in $\mathrm{N}$ metabolism (Kathpalia and Bhatla 2018), which can explain the negative interaction with $\mathrm{NO}_{3}{ }^{-}$. Therefore, higher $\mathrm{N}$ levels in the $+\mathrm{K}$ treatment may be related with a stimulated $\mathrm{N}$ uptake, in the presence of higher $\mathrm{K}$ levels, due to the increased reduction into amino acids. $\mathrm{K}$ and $\mathrm{Zn}$ followed the same trend of accumulation in cones, between treatments, corroborating a synergism between both. Some nutrients presented significant and negative correlations with $\alpha$ - and $\beta$-acids. $\mathrm{N}$ and $\mathrm{Ca}$ were negatively correlated with both $\alpha$-and $\beta$-acids, Mn negatively correlated with $\alpha$-acids, and $\mathrm{Mg}+\mathrm{Cu}$ negatively correlated with $\beta$-acids. Since the hop bitter acid pathway begins with the amino acid precursor leucine (Champagne and Boutry 2017), a higher production of bitter acids will demand a higher supply of amino acids normally through $\mathrm{NO}_{3}{ }^{-}$reduction. $\mathrm{Ca}$ is required in the reduction of $\mathrm{NO}_{3}{ }^{-}$ namely by nitrate reductase kinase ( $\mathrm{Lal} 2018 \mathrm{a}$ ). The results might indicate that higher concentrations of $\mathrm{NO}_{3}{ }^{-}$and $\mathrm{Ca}$ in the cones means lower $\mathrm{NO}_{3}{ }^{-}$reduction, and consequently lower bitter acid production. Regarding $\mathrm{Mn}$, this nutrient competes with $\mathrm{Mg}$ for uptake and also for binding sites in some enzymes (Kathpalia and Bhatla 2018). The Humulus lupulus prenyltransferase-1 (HIPT-1) enzyme that is involved in the first step of bitter acid biosynthesis and the last step of $\beta$-acids production (Champagne and Boutry 2017), exclusively requires $\mathrm{Mg}$ as a divalent cation for its activity and cannot be replaced by other divalent cations (Tsurumaru et al. 2012). Considering the leaf concentration of $\mathrm{Mn}$ and $\mathrm{Mg}$, respectively above and below the sufficiency ranges, perhaps $\mathrm{Mn}$ decreased $\alpha$-acid biosynthesis through $\mathrm{Mg}$ inhibition. The control treatment 
presented higher levels of $\mathrm{Mn}$ and also the lower rates of bitter acids, which seems to be in accordance. $\mathrm{Mg}$ negative correlation with $\beta$-acids may be related with the plant priorities in cone compound production since $\mathrm{Mg}$ is required in many metabolic functions (Lal 2018a; Schulze et al. 2019). The increasing $\mathrm{Cu}$ concentration in hop cones associated with decreasing concentration of bitter acids might indicate a response to a stressful condition such as a disease. Cu acts in plant protection against pathogens (Kathpalia and Bhatla 2018) and hop diseases can significantly reduce bitter acid content in cones (Jelínek et al. 2012).

SPAD readings, NDVI and chlorophyll fluorescence transients did not reveal clear differences between treatments. Only in August 2019, was the NDVI from the $+\mathrm{K}$ treatment significantly higher than that of the AA and control treatments. On the same date, the origin (O) fluorescence transient was significantly higher in the AA than in the control treatment. $\mathrm{K}$ is an important activator of enzymes associated with photosynthesis (Kathpalia and Bhatla 2018) which might suggest that foliar $\mathrm{K}$ sprays $(+\mathrm{K}$ treatment) could have a positive effect on parameters related to the photosynthetic process.

Bitter acids are the most important parameters in hop cone quality for brewing purposes, particularly $\alpha$-acids (Almaguer et al. 2014), and they seem to increase consistently with the application of amino acids as a foliar spray. Significant differences were found for $\alpha$-acids in 2018 (AA treatment higher than control) and for $\beta$-acids in 2018 (AA treatment higher than control) and 2019 (AA treatment higher than $+\mathrm{K}$ and control treatments). Branched-chain amino acid derived compounds are building blocks for the biosynthesis of hop bitter acids, which are produced in large amounts in the lupulin glands of hop cones (Clark et al. 2013), which can explain the positive effect of the AA treatment on the increase of $\alpha$ - and $\beta$-acids.

The application of amino acids and $\mathrm{K}$ as foliar sprays seems to reduce the concentration of total phenols. Jelínek et al. (2012) found a significant increase in total phenols in hop plants as a response of a stressful situation caused by a virus infection. Perhaps less stressed plants, in better nutritional conditions, displayed a reduced concentration in total phenols. On the other hand, results suggest that hop leaves can also be a useful source of polyphenols since the higher values of total phenols were observed in leaves $\left(40.5 \mathrm{mg} \mathrm{g}^{-1}\right.$ extract). However, Abram et al. (2015) and Ceh et al. (2007) found opposite results, with higher levels of phenols to be found in cones. Probably this is the result of the cultivars used in the different studies.

\section{Conclusions}

The amino acid-enriched foliar spray seems to be a competitive alternative to the second side dress $\mathrm{N}$ application carried out by the farmer. The plant biomass production was not affected, and nor was the $\mathrm{N}$ concentration in plant tissues and nitrate concentration in hop cones. Furthermore, the results show a consistent increase of cone bitter acids with the applications of amino acids as a foliar spray, which seems to be relevant to improve crop yield, while reducing the risk of environmental contamination. On the other hand, foliar $\mathrm{K}$ supplementation at cone developing stage did not display a positive result. The yield and quality of hop cones, particularly the size of the cones and the concentration of bitter acids, were not significantly improved by K fertilization in comparison to the control or AA treatments. However, the application of the K-rich foliar spray seemed to increase $\mathrm{N}$ uptake by the roots, with leaves and stems being the predominant allocation tissues. The results also emphasize the importance of amino acids in the biosynthesis of bitter acids in which $\mathrm{K}$ and $\mathrm{Zn}$ also seem to play an important role, perhaps because both are involved in $\mathrm{N}$ metabolism and in its reduction into amino acids.

\section{Conflict of interest}

The authors declare that they have no conflict of interest. 


\section{Funding}

The authors are grateful to the Foundation for Science and Technology (FCT, Portugal) for financial support by national funds FCT/MCTES to CIMO (UID/AGR/00690/2020) and Sandra Afonso doctoral scholarships (BD/ 116593/2016).

\section{ORCID}

Sandra Afonso iD http://orcid.org/0000-0002-2464-8464

Margarida Arrobas (iD) http://orcid.org/0000-0002-4652-485X

M. Ângelo Rodrigues (iD http://orcid.org/0000-0002-5367-1129

\section{References}

Abd El-Razek, E., F. Haggag, M. M. M. Abd-El-Migeed, and E. S. El-Hady. 2018. Combined effects of soil applications of humic acid and foliar spray of amino acids on yield and fruit quality of 'Florida Prince' peach trees under calcareous soil conditions. Bioscience Research 15 (4):3270-82.

Abdelwanise, F. M., S. A. Saleh, M. I. Ezzo, S. S. Helmy, and M. A. Abodahab. 2017. Response of moringa plants to foliar application of nitrogen and potassium fertilizers. Acta Horticulturae 1158:187-94.

Abram, V., B. Čeh, M. Vidmar, M. Hercezi, N. Lazić, V. Bucik, S. S. Možina, I. J. Košir, M. Kač, L. Demšar, et al. 2015. A comparison of antioxidant and antimicrobial activity between hop leaves and hop cones. Industrial Crops and Products 64:124-34. doi: 10.1016/j.indcrop.2014.11.008.

Afonso, S., M. Arrobas, and M. A. Rodrigues. 2020. Soil and plant analyses to diagnose hop fields irregular growth. Journal of Soil Science and Plant Nutrition 20 (4):1999-2013. doi: 10.1007/s42729-020-00210-4).

Ahmad, Z., S. Anjum, E. A. Waraich, M. A. Ayub, T. Ahmad, R. M. S. Tariq, R. Ahmad, and M. A. Iqbal. 2018. Growth, physiology, and biochemical activities of plant responses with foliar potassium application under drought stress- A review. Journal of Plant Nutrition 41 (13):1734-43. doi: 10.1080/01904167.2018.1459688.

Almaguer, C., C. Schönberger, M. Gastl, E. K. Arendt, and T. Becker. 2014. Humulus lupulus- a story that begs to be told. A review. Journal of the Institute of Brewing 120:n/a-314. doi: 10.1002/jib.160.

Bryson, G., H. Mills, D. Sasseville, J. J. Jones, and A. Barker. 2014. Plant analysis handbook III: A guide to sampling, preparation, analysis and interpretation for agronomic and horticultural crops. Georgia: Micro-Macro Publishing.

Ceh, B., M. Kac, I. J. Kosir, and V. Abram. 2007. Relationships between xanthohumol and polyphenol content in hop leaves and hop cones with regard to water supply and cultivar. International Journal of Molecular Sciences 8 (9):989-1000. doi: 10.3390/i8090989.

Champagne, A., and M. Boutry. 2017. A comprehensive proteome map of glandular trichomes of hop (Humulus lupulus L.) female cones: Identification of biosynthetic pathways of the major terpenoid-related compounds and possible transport proteins. Proteomics 17 (8):1600411. doi: 10.1002/pmic.201600411.

Clark, S. M., V. Vaitheeswaran, S. J. Ambrose, R. W. Purves, and J. E. Page. 2013. Transcriptome analysis of bitter acid biosynthesis and precursor pathways in hop (Humulus lupulus). BMC Plant Biology 13 (1):12 doi: 10.1186/ 1471-2229-13-12.

Clescerl, L., A. Greenberg, and A. Eaton. 1998. Standard methods for water and wastewater analysis. Washington DC: American Public Health Association.

Dean, L. 2019. Foliar fertilizer market witnessing increasing penetration of nitrogen-based variants; [accessed 2020 Feb 15]. https://www.worldfertilizer.com/special-reports/22102019/foliar-fertilizer-market-witnessing-increasingpenetration-of-nitrogen-based-variants//.

Dimkpa, C. O., J. Fugice, U. Singh, and T. D. Lewis. 2020. Development of fertilizers for enhanced nitrogen use efficiency - Trends and perspectives. The Science of the Total Environment 731:139113 doi: 10.1016/j.scitotenv. 2020.139113.

Drobek, M., M. Frąc, and J. Cybulska. 2019. Plant Biostimulants: Importance of the quality and yield of horticultural crops and the improvement of plant tolerance to abiotic stress-a review. Agronomy 9 (6):335. doi: 10.3390/ agronomy9060335.

EBC Analysis committee. 1998. Analytica EBC, Hans Carl Getränke Fachverlag, Nürenberg, Method 7.7.

Fageria, N., M. B. Filho, A. Moreira, and C. Guimarães. 2009. Foliar fertilization of crop plants. Journal of Plant Nutrition 32 (6):1044-64. doi: 10.1080/01904160902872826.

Gingrich, C., J. Hart, and N. Christensen. 1994. Hops; [accessed 2019 Apr 13]. https://catalog.extension.oregonstate.edu/fg79/html/. 
Halpern, M., A. Bar-Tal, M. Ofek, D. Minz, T. Muller, and U. Yermiyahu. 2015. Chapter two - the use of biostimulants for enhancing nutrient uptake. Advances in Agronomy 130:141-74.

Hasanuzzaman, M., Bhuyan, M. H. M. B. Nahar, K. Hossain, M. S. Al Mahmud, J. Hossen, M. S. Masud, A. A. C. and Moumita Fujita, M. 2018. Potassium: A vital regulator of plant responses and tolerance to abiotic stresses. Agronomy 8 (3):31. doi: 10.3390/agronomy8030031.

Hawkesford, M., W. Horst, T. Kichey, H. Lambers, J. Schjoerring, I. S. Møller, and P. White. 2012. Functions of macronutrients. In Marschner's mineral nutrition of higher plants, ed. P. Marschner, 3rd ed., 135-89. London, UK: Elsevier.

Ilie, A. V., C. Petrișor, and D. Hoza. 2018. Effect of different amino acid foliar fertilizers on yield and fruit quality of 'redix' apple cultivar. Scientific Papers. Series B. Horticulture 62:101-104.

Jelínek, L., M. Doleckova, M. Karabin, T. Hudcova, B. Kotlikova, and P. Dostálek. 2012. Influence of growing area, plant age, and virus infection on the contents of hop secondary metabolites. Czech Journal of Food Sciences 30 (6):541-7. doi: 10.17221/50/2012-CJFS.

Kathpalia, R., and S. C. Bhatla. 2018. Plant mineral nutrition. In Plant physiology, development and metabolism, ed. S. C. Bhatla and M. A. Lal, 37-81. Singapore: Springer.

Kraiser, T., D. E. Gras, A. G. Gutiérrez, B. González, and R. A. Gutiérrez. 2011. A holistic view of nitrogen acquisition in plants. Journal of Experimental Botany 62 (4):1455-66. doi: 10.1093/jxb/erq425.

Lakanen, E., and R. Erviö. 1971. A comparison of eight extractants for the determination of plant available micronutrients in soils. Helsingin yliopiston rehtorin professori Erkki Kivisen juhlajulkaisu/Viljo Puustjärvi.

Lal, M. A., 2018a. Nitrogen metabolism. In Plant physiology, development and metabolism, ed. S. C. Bhatla, M. A. Lal, 425-80. Singapore: Springer.

Lal, M. A., 2018b. Sulfur, phosphorus, and iron metabolism in plants. In Plant physiology, development and metabolism, ed. S. C. Bhatla and M. A. Lal, 481-515. Singapore: Springer.

Lambers, H., F. S. Chapin, and T. L. Pons. 2008. Mineral nutrition. In Plant physiological ecology, ed. H. Lambers, F. S. Chapin and T. L. Pons, 255-320. New York (NY): Springer

McAllister, C. H., P. H. Beatty, and A. G. Good. 2012. Engineering nitrogen use efficient crop plants: The current status. Plant Biotechnology Journal 10 (9):1011-25. doi: 10.1111/j.1467-7652.2012.00700.x.

Noroozlo, Y. A., M. K. Souri, and M. Delshad. 2019. Effects of foliar application of glycine and glutamine amino acids on growth and quality of sweet basil. Advances in Horticultural Science 33 (4):495-501.

Procházka, P.,. P. Štranc, K. Pazderů, J. Vostřel, and J. Řehoř. 2018. Use of biologically active substances in hops. Plant, Soil and Environment 64 (12):626-32. doi: 10.17221/655/2018-PSE.

Schulze, E. D., E. Beck, N. Buchmann, S. Clemens, K. Müller-Hohenstein, and M. Scherer-Lorenzen. 2019. Nutrient relations. In Plant ecology, ed. E. D. Schulze, E. Beck, N. Buchmann, S. Clemens, K. MüllerHohenstein and M. Scherer-Lorenzen, 367-99. Berlin: Springer.

Shehata, S.,. H. S. Abdel-Azem, E.-Y A. Abou, and A. El-Gizawy. 2011. Effect of foliar spraying with amino acids and seaweed extract on growth chemical constitutes, yield and its quality of celeriac plant. European Journal of Scientific Research 58 (2):257-65.

Shehata, S. A., M. M. El-Mogy, and H. F. Y. Mohamed. 2019. Postharvest quality and nutrient contents of long sweet pepper enhanced by supplementary potassium foliar application. International Journal of Vegetable Science 25 (2):196-209. doi: 10.1080/19315260.2018.1523816.

Small, E. 2016. Hop (Humulus lupulus)-A bitter crop with sweet prospects. Biodiversity 17 (3):115-27. doi: 10. 1080/14888386.2016.1199327.

Temminghoff, E. E. J. M., and V. G. Houba. 2004. Plant analysis procedures, ed. E. J. M. Temminghoff and V. J.G Houba, 2nd ed. Netherlands: Springer

Tsurumaru, Y., K. Sasaki, T. Miyawaki, Y. Uto, T. Momma, N. Umemoto, M. Momose, and K. Yazaki. 2012. HIPT-1, a membrane-bound prenyltransferase responsible for the biosynthesis of bitter acids in hops. Biochemical and Biophysical Research Communications 417 (1):393-8. doi: 10.1016/j.bbrc.2011.11.125.

Turner, S. F., C. A. Benedict, H. Darby, L. A. Hoagland, P. Simonson, J. R. Sirrine, and K. M. Murphy. 2011. Challenges and opportunities for organic hop production in the United States. Agronomy Journal 103 (6): 1645-54. doi: 10.2134/agronj2011.0131.

Valentinuzzi, F., M. Maver, S. Fontanari, D. Mott, G. Savini, R. Tiziani, Y. Pii, T. Mimmo, and S. Cesco. 2018. Foliar application of potassium-based fertilizer improves strawberry fruit quality. Acta Horticulturae 1217 (1217):379-84. doi: 10.17660/ActaHortic.2018.1217.48.

Van Reeuwijk, L. 2002. Procedures for soil analysis. Technical Paper 9. Wageningen: International Soil Reference and Information Centre.

Yu, F., X. Wang, Y. Yao, J. Lin, Y. Huang, D. Xie, K. Liu, and Y. Li. 2020. Manganese accumulation and plant physiology behavior of Camellia oleifera in response to different levels of potassium fertilization. International Journal of Phytoremediation 22 (10):1075-10. doi: 10.1080/15226514.2020.1726871. 